\title{
The Postcolonial Pedagogical Challenge of Creativity
}

\section{Sabrina D. MisirHiralall}

To cite this article: Sabrina D. MisirHiralall (2017): The Postcolonial Pedagogical Challenge of Creativity, Religion \& Education, DOI: 10.1080/15507394.2017.1335561

To link to this article: http://dx.doi.org/10.1080/15507394.2017.1335561

Accepted author version posted online: 26

May 2017.

Published online: 26 May 2017.

Submit your article to this journal $₫$

Џ Article views: 5

Q View related articles $\sqsubset$

View Crossmark data $[\pi$ 


\title{
The Postcolonial Pedagogical Challenge of Creativity
}

\author{
Sabrina D. MisirHiralall
}

\begin{abstract}
Edward Said pointed to the problem of Orientalism that develops when the West creates a fictitious imagined version of Eastern religion and culture. Said's notion of Orientalism focuses on the general distorted representation of Eastern religion and culture by the West. Homi Bhabha extends Said's notion of Orientalism to reveal the tension of the inevitable hybridity between the East and the West. Here, cultural practices develop in the space of hybridity with the intention to promote a feeling of coherence as opposed to with the objective to deform or distort religion and culture. Thus, the intention in a space of hybridity is often not to engage in Orientalism. Instead, the goal is to develop something new in a hybrid form. An opportunity arises in philosophy of education to adequately confront the problem of Orientalism that may develop in a space of hybridity. The author proposes a philosophical postcolonial framework that engages in a creative process that does not further Orientalism but rather develops something new with an ethic of hybrid responsibility for religion and culture. To illustrate this, the author uses Kuchipudi Indian Classical Hindu dance as an example.
\end{abstract}

\section{KEYWORDS}

Creativity; dance; Hinduism; postcolonialism

Because creativity has the potential to misappropriate religion and culture, there is a call for educators to philosophically treat creativity. A consideration of Eastern and Western philosophies of education has the potential to improve teaching. The West and the East are illusionary binaries where cultures inevitably intertwine. Homi Bhabha's central concept of hybridity ruptures the paradoxes by not just recalling the past but refiguring the past in a manner that interrupts the present. ${ }^{1}$ Illusionary boundaries are displaced because of the diasporic nature of religion and cultures. Bhabha ${ }^{2}$ shows that paradoxes such as "home and world" and "private and public" come together because the boundaries are illusionary. The space of hybridity ruptures the paradoxes to become infused with something new. This unity that brings together the paradoxes is Bhabha's solution to the dire problem of confinement caused by illusionary boundaries. This unity needs to remain sensitive to the problem of Orientalism that has the potential to colonize. Edward Said $^{3}$ illustrates how Orientalism thrives when the West often develops

Sabrina D. MisirHiralall, Ed.D., defended her dissertation, "De-Orientalized Pedagogy: Educating Non-Hindus about Hinduism Through Kuchipudi Indian Classical Hindu Dance" at Montclair State University. She currently serves as Regional Coordinator for the Mid-Atlantic Region of the American Academy of Religion. MisirHiralall.S@gmail.com Color versions of one or more of the figures in the article can be found online at www.tandfonline.com/urel. 
imagined histories of Eastern religion and culture. If the religious and cultural identity that forms through the germination in the space of hybridity develops with postcolonial realities in mind, then there is a possibility for a new religious and cultural identity to form that takes into account a humanitarian culture.

For Bhabha, ${ }^{4}$ newness is always present because cultures are always in contact with one another. We should pay close attention to newness particularly in the pedagogical space of hybridity with sensitivity to cultures in mind. Before creativity is used to transfuse cultures with some sort of newness, it is crucial to engage in de-Orientalized interreligious dialogue and cultural contact to help maximize the efficiency of the creative process. ${ }^{5}$ It is necessary to comprehend religion and culture to prevent a hazardous distortion based on Orientalist understandings. In other words, the creative process needs to be mediated by building the prior knowledge of learners in a manner that pursues a de-Orientalized understanding of religion and culture. This is central to a sensitive approach to creativity that does not aim to cause harm to Eastern or Western religion and culture.

Bhabha illustrates this as he relates how religion and culture transforms during the creative process.

The borderline work of culture demands an encounter with 'newness' that is not part of the continuum of past and present. It creates a sense of the new as an insurgent act of cultural translation. Such art does not merely recall the past as social cause or aesthetic precedent; it renews the past, refiguring it as a contingent "in-between" space, that innovates and interrupts the performance of the present. The "past-present" becomes part of the necessity, not the nostalgia, of living. ${ }^{1}$

Bhabha clearly states "creates a sense of the new" as he points to a newness that forms from the fusing of elements, which causes the components to develop into a new entity while retaining features of the old. For this reason, individuals should exercise an ethic of hybrid responsibility for religion and culture. If the creative process goes unmediated, then a lack of sensitivity has the potential to develop something new that prompts Orientalist and colonialist agendas to flourish. Essentially, Western and Eastern ideals will remain tangled in the space of hybridity unless a de-Orientalized comprehension of religion and culture untangles the knot to provide room for a creative process that is sensitive to unequal power relations.

De-Orientalized knowledge develops when there is an understanding of religion and culture through interreligious dialogue and cultural contact that does not distort or deform religion and culture as evident in Orientalism. In the pedagogical space of hybridity, the goal is not to teach about confined Western and Eastern values but rather to sprout something new with sensitivity to the nature of religion and culture that exists in illusionary worlds, where systematized dominative powers engage in misappropriation that 
provokes exoticism. The newness that develops should sustain an ethic of hybrid responsibility, which works pragmatically for the East and the West.

In this article, I engage in a self-study to develop a philosophical framework that confronts the presence of Orientalism in the creative process. The selfstudy methodology ${ }^{6}$ is a viable philosophical research method that focuses on improvement-aimed pedagogy. I am a Kuchipudi Indian classical Hindu dancer who aims to teach primarily non-Hindus in higher education about Hinduism with postcolonialism in mind through the medium of dance. It is crucial to note that Hindu dance developed during ancient times. According to Hindu metaphysics, ${ }^{7}$ there are four ages (Yugas) of this world. The first age is Satya Yug. Humankind aspired to maintain the purest ideals in this Yug. The second age is Treta Yug. Desire began to plague humankind, which caused a need to tame the five senses. The third age is Dwapara Yug. Individuals became focused on self-interest. The fourth age is Kali Yug. There is an emphasis on the need for material objects in this current age of Kali Yug. It is important to note that Hindu metaphysics is immensely distinctive when compared to Western metaphysics. The prominent text, The Yugas, ${ }^{7}$ describes Hindu metaphysics with a critical analysis that sheds light on the vast differences between Western metaphysics and Hindu metaphysics.

At any rate, One Supreme Being, who manifests in different forms, at different times, and for different purposes, created Hindu dance in Treta Yug to tame the senses and provide an avenue for the dancer and viewers of the dance to think about Hindu ethics. With the intended purpose of Hindu dance in mind, Sage Bharata, as instructed by the Supreme Being, penned the famous Natya Shastra, ${ }^{8}$ which is a text that relates the Hindu ethic of dance. In addition, Sage Nandikeshvara wrote the Abhinaya Darpanam ${ }^{9}$ to develop a language of Hindu dance, as instructed by the Supreme Being. Hindu dance has specific hand gestures, feet gestures, eye gestures, head gestures, neck gestures, emotions, and so forth. Each gesture has a specific meaning. When a series of gestures are composed, it creates meaning that viewers of the dance can interpret if they comprehend the language of dance.

Most importantly, the Natya Shastra provides guidelines for the dancer to maintain before the dance, during the dance, and after the dance. For example, ${ }^{10}$ before the dance, the dancer transforms into the dancer during a contemplative dressing process where the dancer engages in the concept of interbeing to focus on interconnection to the elements of the earth that make up the composition of the jewels, clothing, and so on (see Figure 1). The dancer should not concentrate on a superficial sense of beauty but instead should center on connecting to the elements of the earth with the purpose of the dance in mind. Before the dance, the dancer prays on the stage for One Supreme Being to manifest in different forms to protect the dancer and guard the stage. During the dance, the dancer transforms into characters to present ethical dilemmas that are meant to relate the history of Hinduism in an effort 


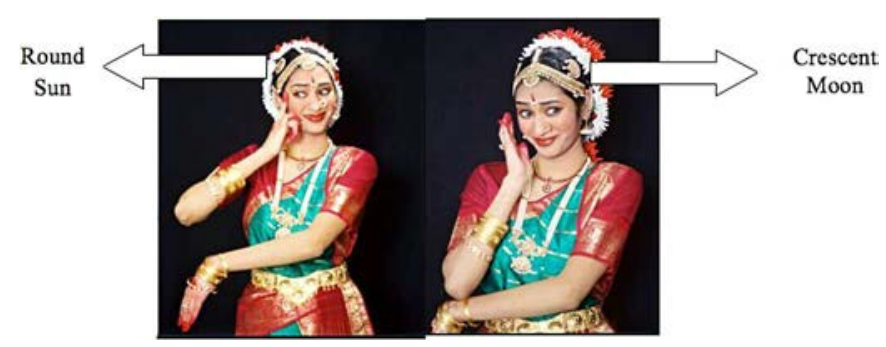

Figure 1. Example of the author wearing traditional Indian classical Hindu dance jewelry. The round sun jewel symbolizes Surya, the Sun Devata (God). The crescent moon symbolizes Chandra, the moon Devata (God). From One Supreme Being, the many emerge.

to teach about morality. The dancer may also engage in rhythmic movement to provoke a sacred phenomenological feeling for the dancer and the viewers of the dance. After the dance, the dancer should continue to walk a path of moksha, which means that the dancer seeks to live a virtuous life to pursue freedom of reincarnation and liberation upon death.

Because Hindu dance is rooted in an ethic of Hinduism, Hindu dancers cannot strip the sacredness of Hindu dance. To ignore the rituals of Hindu dance is to distort Hindu dance in a manner that desecrates the tradition. Those who call themselves "Hindu" dancers but do not have any intention to adhere to the ritual and ethical dimension of Hindu dance as portrayed in the Natya Shastra are not "Hindu" dancers but rather are cultural dancers who distort Hindu dance by calling it "Hindu." The essential goal of the Hindu dancer is to engage in Hindu dance as a medium to provoke a sacred phenomenological experience for the viewers of the dance to attain moksha (liberation) and for the dancer to move toward moksha (liberation) upon death.

Although I give examples of the creative process in dance, the philosophical framework that I propose for the creative process that exercises an ethic of hybrid responsibility is transferable to other disciplines. My personal dance journal is my main source of data. After I dance, I write in a dance journal and deliberate with my peer scholars ${ }^{11}$ who help me to move deeper into a philosophical analysis. I will focus on two dance events from my dance journal in this article. First, I share how my self-study causes me to acknowledge that I unintentionally furthered the Orientalism of Indian classical Hindu dance through a creative process when I choreographed a particular dance piece. Second, I share how I repeatedly return back to the pedagogical space of hybridity as I attempt to engage in a creative process that applies de-Orientalized knowledge of Hinduism. To press the point, I now turn to shed light on how American dance pioneers, Ruth St. Denis ${ }^{12}$ and Ted Shawn ${ }^{13}$ furthered the Orientalism of Hindu dance because they applied Orientalist knowledge in the pedagogical space of hybridity without sensitivity as they produced something new. 


\section{Creativity of American dance pioneers}

During the early 1900s, American dance pioneers used creativity in the space of hybridity to blend Eastern and Western dance forms. Particularly, Ruth St. Denis (1879-1968) and Ted Shawn (1891-1972) were American dance pioneers who formed the Denishawn Compay. ${ }^{14}$ They traveled to India where they learned the basics of Indian classical Hindu dance. With a very basic education of Indian classical Hindu dance, Ruth St. Denis and Ted Shawn developed a very unique creative dance style that Orientalized Indian classical Hindu dance as they blended elements of the East with elements of the West in an irresponsible manner.

St. Denis and Ted Shawn did not study under a traditional Hindu dance guru. Because of this oversight, St. Denis and Ted Shawn did not learn about the sacredness of the Hindu ethic of dance or the Hindu language of dance. Instead, they studied an imagined Hinduism through Western authors who maintained an Orientalist lens. This is a clear example of a lack of an ethic of hybrid responsibility.

Ruthie had heard of the mythical maiden Radha in Edmund Russell's readings from
The Light of Asia. She learned more about her in a series of books she owned, Great
Religions of the World. In one volume of that series she found a suitable theme for
her heroine to dance in A.C. Lyall's essay on Brahmanism. As Lyall wrote, "If a
Hindoo be asked what is the object and ultimate good that he is striving to reach
through religious rites, he will answer 'Liberation.' He must free his soul, the divine
particle, from the bondage of the senses." Guided by this dramatic idea, Ruthie set
about the creation of her temple dance."15

St. Denis, in particular, studied about the great Hindu female Radha through Orientalized sources. For this reason, she believed Radha is a mythical maiden as opposed to a historical female of Hinduism. St. Denis also learned that liberation is the most important concept for Hindus. However, St. Denis does not understand moksha (liberation) or the Hindu's method for attaining moksha. St. Denis uses the creative process to develop a mythological dance drama about a historical Hindu female Radha. She also develops a misguided representation of the sacred Hindu concept of moksha, which then she uses as a theme in her theatrical performance. Nevertheless, St. Denis did encounter traditional, respected Hindus.

Americans of St. Denis's generation encountered Vedanta indirectly through the writings of European philosophers such as Schopenhauer or the America Transcendentalists, particularly Ralph Waldo Emerson, who studied the Bhagavad-Gita and the Upanishads in translation and adapted the Vedic concept of a universal spirit to this own definition of an Oversoul. A more direct introduction of Vedanta to the Western world came through a landmark event, the World Parliament of Religions at the World's Columbian Exposition in Chicago in 1893. One of the delegates to that convocation was an Indian swami, Vivekananda, whose flowing robes and 
yellow turban and clear exposition of Vedanta made him the popular favorite of the parliament. ${ }^{16}$

Although St. Denis studied Vedanta through Western scholars, there was an opportunity for St. Denis to listen to Swami Vivekananda speak at the World Parliament of Religions. Even though Swami Vivekananda is a respected scholar of the Vedas, he was not a guru of Hindu dance. If St. Denis had a desire to gain knowledge of Hindu dance, she needed to study under a revered guru of dance. Nevertheless, St Denis pursued the study of Vedanta on her own with limited guidance from respected gurus.

In 1908 in the company of Constance Smedley, she traveled from London to Surrey to meet Swami Paramananda, a disciple of Vivekananda and a member of the Ramakrishna Order. ... Swami Paramananda was Ruth's initiator, the first authentic teacher of Vedanta she had encountered, though she had come across "a number of fake Yogi, trading on women's leisure and curiosity." Her meeting with the Swami marked the "beginning of a liberal and spiritual education." 17

Based on St. Denis's limited encounters with respectable Hindu gurus, she developed an Orientalized dance style that did not exercise an ethic of hybrid responsibility for religion and culture. St. Denis and nontraditional Indian dancers performed a newly developed creative dance style with Oriental themes in India. This is very problematic because St. Denis irresponsibly creates an Orientalized dance style which she then teaches to Indians who were not dance students of dance gurus. Once again, there is the issue of creativity in the educational process. Indians should not have expected a Westerner who did not study Hinduism deeply or Hindu dance, to teach them about Hinduism through dance. I do not claim that all Indians have knowledge of Hindu dance or that all non-Indians lack knowledge of Hindu dance. My point is that if anyone, Indian or non-Indian, wishes to learn Hindu dance, then there is an appropriate educational process to follow as prescribed by the Hindu ethic of dance. The Natya Shastra ${ }^{18}$, the sacred Hindu text that relates the ethic of Hindu dance, states that anyone who studies Hindu dance should learn from a respected, Hindu guru of dance who is well versed in Hindu theoretical texts.

Perhaps, Bhabha would contend that St. Denis brings forth the possibility of newness while in a space of hybridity. St. Denis had the potential to develop a new kind of dance that was neither Hindu nor Western. Yet, St. Denis presents her dances as Hindu, which is precisely where the problem occurs. Essentially, the presentation of the dance as Hindu causes Orientalism to flourish. Although St. Denis's creative insight is valuable, her creativity misrepresents Hinduism and Indian culture, which adds to Orientalist interpretations because St. Denis uses creativity to portray an imaginary mythological interpretation of Hinduism and Indian culture. Hindus would concur that Hinduism is not an imaginary, make-believe religion. Scholars should attempt 
to understand the nature of Hinduism from Hindu scriptures as opposed to Orientalized, mythological interpretations. In the following quote, it is evident that St. Denis had a desire to integrate the mind-body connection of Hinduism in her creative dance style. This is very admirable but becomes problematic when Hindu themes are used in an Orientalized manner.

\begin{abstract}
Ruth's initial interest in the dances of India had to do with her desire to combine the spiritual with the theatrical, and to do so she felt her dance must be grounded in 'high ideas' of philosophy, art, and religion, characteristics Ruth felt were abundant in Hindu culture. Between 1905 and 1906 Ruth created three important works for herself based on Hindu themes; the original work Radha, and then Incense, and the Cobras. $^{19}$
\end{abstract}

My issue does not lie with St. Denis's creative style but rather is with the Orientalized usage of Hinduism as her main theme. St. Denis caused Orientalism to flourish because her creative interpretations did not use a de-Orientalized knowledge base. For example, St. Denis played the Hindu female Radha in her original work Radha. Radha is a divine female in Hinduism who is a consort of the Supreme Being, who manifested as Shri Krishna in Dwapara Yug. St. Denis wore Indian garb as she played the role of Radha in the ballet. A picture of Ruth St. Denis on the cover of Moving History Dancing Cultures depicts Ruth St. Denis in a Western dance pose as the divine Radha. This pose of the body coupled with the clothing is exotically vulgar among traditional Indian classical dance scholars because the pose flexes the body in a manner in which the exoticism is clearly explicit. It is a false representation of Radha as a divine being of Hinduism.

St. Denis's blended dance styles of the East and the West does not adhere to how traditional Hindus would portray the divine Radha. The choreography of St. Denis confuses Middle Eastern belly dance and traditional Indian classical Hindu dance. St. Denis composes an intriguing choreography, ${ }^{20}$ which is very creative but it is not Indian classical Hindu dance. On the contrary, it should be acknowledged as a fusion of an Eastern dance style and a Western dance style that is a new type of dance style developed with creativity in the space of hybridity. On the one hand, St. Denis was a dance pioneer who thrived on intercultural relations. On the other hand, she irresponsibly disregarded the sacredness of Hindu dance as she wore the sacred Hindu dance bells without acknowledging the ritualistic, sacred dance traditions of Hinduism even though Hinduism is a common theme across her Oriental dances. In this sense, she engages in Hinduism as a form of culture and not as a religious way of life for the dancer. Although she advocated for spirituality in dance, she did not focus on the religious nature of Hinduism as part of the dance.

For instance, Ruth St. Denis did not engage in sacred Hindu contemplative practices that occur before the dancer dances on stage. Indian classical 
dance ballets traditionally begin behind the curtains as the dancer performs puja on stage.

This adoration of the deities of the stage is on par with a Yajna (holy sacrifice). No one shall produce a play without the worship of the stage. These deities worship others when they themselves are worshipped. When they are honoured [sic], they bestow honour [sic] to others. Hence one shall assiduously perform the rite of the adoration of the (deities of the) stage. ${ }^{21}$

Bharatamuni relates the importance of worship before the dance performance in the Natya Shastra. Please note that Hindu scriptures state Hinduism is a monist religion that believes there is One Supreme Being. ${ }^{22}$ However, from the One, the many emerge for different purposes. Nevertheless, the many is still a part of the One. The dancer prays for protection during the performance and also prays to unite with a Supreme Being through the performance. Moreover, the dancer hopes to serve Hinduism by relating the great epics of Hinduism with the intention of philosophizing about moral duty.

Ruth St. Denis used incense and sacred Hindu religious objects as props instead of for worship. This is quite offensive to Hindus who maintain respect for sacred religious objects. Nevertheless, a majority of Indians did not confuse St. Denis's creative dance style with traditional, religious Hindu classical dance traditions such as Bharatnatyam or Kuchipudi. Rather, most Indians seem to appreciate the creative attempts of the West to understand the nature of the religion and culture of India.

Dances with oriental themes were initially performed in India by Europeans or Europe-based Indian classical dancers, including the Denishawn Company on their 1926-27 tour, and a few years later by Uday Shankar, returning to India after ten years in Europe. These oriental dances were never mistaken by Indians for their own dance forms; rather they were appreciated attempts by artistes to stage dance with Indian themes and costumes. ${ }^{23}$

Perhaps, St. Denis could have created new imaginative characters to blend the dance styles of the East and the West with sensitivity to Hindus and Indian culture in mind. It is important to care about a misrepresentation of Hinduism and Indian culture because it provides false knowledge, thus adding to the dangers of Orientalism. In fact, it brings a whole new problem to the field of Orientalism. That problem is this notion of Oriental dance. Oriental dance, in this sense, does not show respect for the traditions of Hinduism. St. Denis secularized Hindu religious practices and thus caused Orientalism to flourish in a profane manner. This becomes offensive to traditional Hindu dancers. Just as those who are not baptized should not participate in the Eucharist part of Catholic services or those who are not Jewish need to be cautious of practicing sacred Jewish traditions such as wearing a tallit (Jewish prayer shawl), those who do not adhere to the religious aspect of Hinduism should not claim to be Hindu dancers. It is unfortunate that creativity can 
show disrespect for religion if it does not use a de-Orientalized pedagogical stance.

I do not claim that Hindu dance must remain static and unchanging. What I do claim is that regardless of whether Hindu dance is situated in ancient times or contemporary times, there is a need to stay faithful to the Hindu ethic of dance if choreographing Hindu dance. Otherwise, Hindu dance moves away from Hinduism and transforms into something new that is no longer Hindu. As Said's political analysis implies, ${ }^{24}$ this will result in an obliteration of Hinduism that further universalizes Western ideals through the perpetuation of Eastern stereotypes. If dancers do not respect the ethical base of Hindu dance, then the choreography is no longer Hindu. Furthermore, the dance piece is essentially not a hybrid interaction of traditions but rather represents a radical break with Hindu tradition that propagates Western Orientalism. Although there is a need in the pedagogical space of hybridity to move cross the illusionary boundaries of diasporic cultures, there is also a need to adhere to the Hindu ethic of dance to prevent the extinction of a sacred tradition that has the capability to adopt to the un-static nature of cultures.

At first, this pedagogical space might look very messy because of the possible tension between individuals who are unaware of each other's identity, religion, and culture. This messiness slowly begins to transform through hybrid pedagogy as everyone responsibly comes together to develop a deOrientalized epistemological framework and share a part of personal identity. With the identity of individuals coupled with a de-Orientalized epistemological framework in mind, there is a call for negotiation in this space. Individuals rethink how to remain in fidelity to tradition, based on identity, while also sharing but not imposing tradition onto others. This is precisely when an ethic of hybrid responsibility for religion and culture is at play. The space becomes a harmonious unsoiled area that develops inter-religious and intercultural relations. Yet, this is paradoxical because this peaceful neat space is constantly re-entering a messy place because of the need to always rethink religion and culture that does not remain at a standstill. To press this point, I turn to relate how I engaged in the creative process in a pedagogical space of hybridity as I choreographed dances that aim to teach about Hinduism.

\section{Self-study of the creative process}

During Fall 2009, I was asked to perform at a cultural charity event to raise funds for Ganesh Shiva Mandir, ${ }^{25}$ a West Indian ${ }^{26}$ Hindu temple in Jersey City, NJ. At first, I declined the request to dance because the coordinators asked me to perform a Bollywood dance. ${ }^{27}$ Varia states that no one really knows when the term Bollywood developed. ${ }^{28}$ Varia defines Bollywood as, "Hindi-language based and populist cinema produced by major studios in 
Mumbai India." 29 Throughout time, Bollywood dance came to move traditional Indian dance away from traditional, religious dance and toward Western ideals of dance as a form of entertainment and socialization. Even though Bollywood has the potential to be a productive space where cultures intersect, it is not the focus of my goal as a Hindu dancer. I am a traditional, Kuchipudi Indian classical Hindu dancer who desires to connect to a Supreme Being through dance. Although Bollywood has its own merits, I do not claim to be a Bollywood cultural dancer. I once danced Bollywood dances to express my feelings to loved ones but have moved away from a cultural form of dance and toward a sacred dance genre that aims to connect to a Supreme Being. Perhaps, I may return at some point to a form of Bollywood dance that develops in a pedagogical space of hybridity with a de-Orientalized knowledge base.

Nevertheless, the coordinators of the event pleaded with me to perform. I offered to dance a traditional, Kuchipudi dance but the coordinators did not desire a religious dance for this event. After coming to terms with the request, I eventually decided to meet the appeal. Here, I faced a struggle because I had to use creativity to choreograph a Bollywood dance while remaining faithful to my own religious identity as a Hindu dancer. I chose an upbeat-remixed version of a Bollywood song, Aja Maahi. ${ }^{30}$ I added a classical instrumental ${ }^{31}$ piece to start the dance piece. I used creativity to apply the language of Indian classical dance to implicitly choreograph the dance with love for Shri Krishna, ${ }^{32}$ who represents a manifestation of the One Supreme Being in Hinduism. Princess Mirabai, ${ }^{33}$ a contemporary Hindu Princess who danced with sincere devotion for Shri Krishna, inspired me implicitly. She adored Him as her spiritual husband even though she was married to Prince Bhoj. ${ }^{34}$ As I choreographed the dance, I integrated Bollywood movements and classical movements with Princess Mirabai in mind as I attempted to blend the traditional and the modern. I did not know that the hardest part of my struggle with my use of creativity in this dance would not come until during and after the performance.

My phenomenological experience during the dance was surprising to me as well as my peer scholars. I wore a traditional, Indian saari, which Hindu devotees would wear to a Hindu temple. I had great difficulty with blending sacred traditional clothing and modern Indian cultural wear. Because I did not want to disrespect my sacred traditional dance costume and jewels, I did not wear any of those pieces. Instead, I wore modern Indian cultural wear albeit a traditional type of clothing. This created a sense of discomfort for me because it was almost as if this warranted an exotic gaze due to the nature of the Bollywood genre of dance that often Orientalizes Indian female dancers to conform to Western ideals.

On the one hand, I had a self-perception of myself as a sacred dancer but on the other hand, there was an overwhelming exotic gaze from the spectators. I felt as if neither gaze overpowered the other but rather met robustly as I danced. The hybrid gaze that I sensed was untamed due to a lack of a 
de-Orientalized, hybrid pedagogy. Because there was no opportunity for me to use the dance pedagogically to teach, because this was a cultural event for a religious organization, I feel I did not have the chance to negotiate the gazes in the pedagogical space of hybridity. I was asked to perform not to teach. Regardless, there needs to be a hybridization between "performing" and "teaching." Orientalism is present when the dance as entertainment dominates the goal to teach. I essentially call for teaching to overshadow the dance as entertainment to prevent the advancement of Orientalism.

My peer scholars and I came to insightful conclusions through the deliberations as we analyzed my self-study journal. First, I admit that I ironically became more aligned with the position of Ruth St. Denis. The dance that I choreographed was hybrid based on Bhabha's theory of hybridity. Although I did pay attention to the spirituality of the dance, my choreography developed something new that tragically misrepresented Hinduism. This leads me to acknowledge the importance of entering the space of hybridity with sensitivity because what develops may potentially add to Orientalism. I must understand my role as a religious Hindu dancer and educator. Overall, I am not merely a performer but rather a teacher whose purpose is to teach regardless of the pedagogical space in which I dance. I learned that there must be certain circumstances present for me to dance. One of the circumstances is that I must have the opportunity to use dance pedagogically to teach. In other words, I should not be approached as a mere performer but rather I should be received as a teacher. Another circumstance is that I need to dance in pedagogical spaces that warrant a de-Orientalized educational gaze. If I dance in a cultural event, then I as a religious Hindu dancer am reduced to a cultural object that might unintentionally provoke an exotic gaze. To call sacred Indian classical Hindu dance "cultural" strips Hindu dance of its core-the sacred religious component.

To return to the abovementioned event, my dance seemed enjoyable to the audience, but I unintentionally misrepresented Indian classical Hindu dance because of the way I used creativity. I remember my mother, who did not attend the performance due to geographical distance, called me after the performance to relate the disappointment of so-called traditional, religious critics. Apparently, many religious critics were not pleased with the way I creatively used dance, although many cultural critics thought the dance gave me a new "flare" away from the traditional way I dance. Whether or not this criticism is exaggerated or fictional, as a religious Hindu dancer, it is essential to use religious dance to enrich Hinduism regardless of the circumstances. Critics will have several criticisms that I need not concern myself with. The critics that I must concern myself with are my respected gurus, peer scholars, and my own self-reflection.

Although it seems like I Orientalized the dance, there is a broader context of exoticism that influences how the dance becomes an Orientalized product. 
I did not engage in an Orientalist choreography that disrespected Hinduism and the ethic of Hindu dance. On the contrary, I used my inner spiritual third eye to choreograph a dance piece that conveyed emotions to Shri Krishna through a contemporary Bollywood medium. Yet, the legacy of Orientalism worked against me, as many individuals did not maintain a de-Orientalized knowledge base of the dance. In this case, a postcolonial reality unavoidably works through me although I did not intend it. Through the choreography coupled with the gaze of the viewers, the dance became a product of Orientalism.

From this experience, I learned that when I use creativity to integrate religious ideals with Bollywood, it must be done with more sensitivity to the religious nature of the dance. If religious dance becomes integrated into Bollywood, it has the potential to become a form of culture that does not necessarily remain faithful to the religious ideals of the dance form. The religious aspect of the dance, unfortunately, becomes a mere notion of culture if viewers cannot see the spirituality of the dance through their inner spiritual third eye. With this concern in mind, I must position myself within a larger social and political context that acknowledges how exoticism works through Orientalism as I choreograph hybrid dance forms.

I developed a dance piece in the space of hybridity as I fused my knowledge of Hindu dance with the ideals of Bollywood. Although I maintained a deOrientalized framework that considered postcolonial realities, I did not pay attention to the way Orientalism works through me when I dance. This minimized the efficiency of the creative process as I developed a hybrid dance piece. My body was reduced to a scarred body of the Orient that provoked an exotic gaze. Although I choreographed the dance with Princess Mirabai ${ }^{34}$ in mind, I was unable to teach the spectators about my interpretation of the dance piece. Furthermore, the costume that I wore revealed the body in a way that was no longer protected by the sacred jewels of traditional Indian classical dance. I could not wear a traditional Kuchipudi costume for the dance because this would clearly dishonor and Orientalize the tradition since the jewels and costumes are to be worn at specific times for precise purposes on particular occasions. The Kuchipudi costume is sacred in the tradition. ${ }^{10}$ It should not be worn to perform any dances outside of a strictly religious, Hindu, sacred framework.

The traditional Kuchipudi costume shows the dancer's appreciation for material objects that symbolize the beauty of creation. The dancer traditionally wears jewels of the sun and the moon on the head. The dot in the center of the forehead is symbolic of the contemplative third eye that helps with ethical decision-making. The mind and the body unite through the language of Indian classical Hindu dance to help the dancer live ethically in this world so that upon death, the dancer gains moksha (liberation) as the dancer merges with a Supreme Being. 


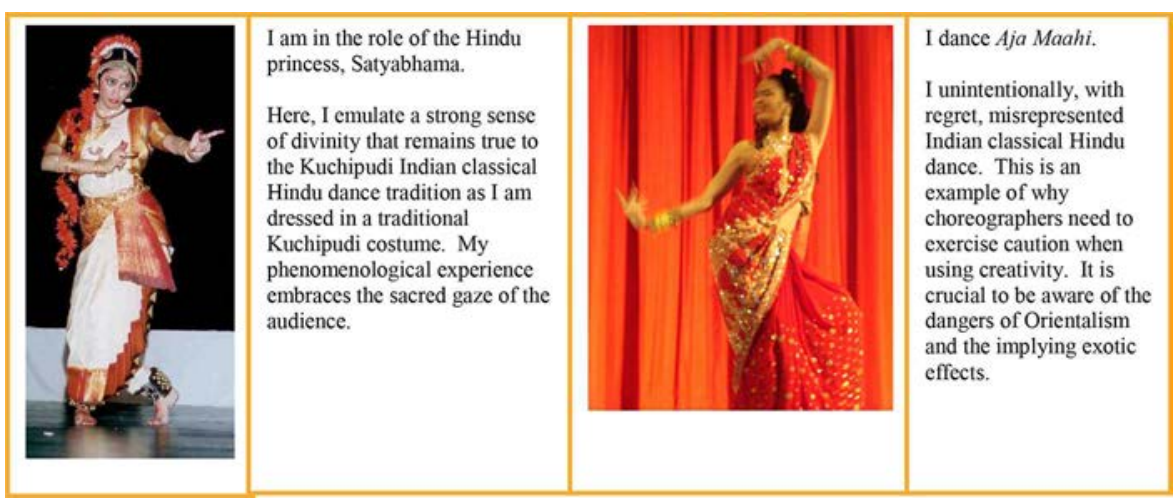

Figure 2. Differences in the dancer's dress narrative.

I wore a saari, a long-length cloth that wraps around the body, along with fashionable costume jewelry. I also wore my hair down, which further mimicked the distortion of Indian women as erotic creatures of the Orient (see Figure 2). I felt unprotected as I danced in an uncanny space where the screams and hooting from the audience chilled my body with the scars of an exotic gaze. Although the dance elicited this reaction, it is crucial to remember that this response stems from a long history of Orientalism that influences how Hindu dance and Bollywood dance are received in the West among Hindus and Indians. This is an internalized type of Orientalism due to the residual effects of colonization. What is at stake is essentially my own lack of how a social and political background informs the reception of Hindu dance and Bollywood dance in the West. This is important to understand because this always informs the gaze of the viewers. Although the dance maintains a de-Orientalized choreography of a hybrid dance form, I need to be more sensitive to postcolonial realities as I choreograph hybrid dance pieces.

My phenomenological experience from the above-mentioned event inspired me to attempt to engage in a creative process that enriches the Hindu dance tradition with an ethic of hybrid responsibility in mind. A few years later my niece asked me to perform a Bollywood dance with her. My niece and I performed Mere Dholna ${ }^{35}$ for the Hindu organization, GyaanKaSaagar's ${ }^{36}$ annual Mother's Day cultural event. Although I faced great discomfort in the above-mentioned event when I engaged in the creative process, I did not resist the inevitable space of hybridity where cultures are bound to intersect. Instead, I entered the pedagogical space of hybridity with more sensitivity as I used a de-Orientalized knowledge base of Hindu dance and Bollywood dance to develop something new.

I listened to the semi-classical song, which had many traditional classical beats. I choreographed a three-scene dance piece. I engaged in hybrid pedagogy as I taught my niece about the devotion Princess Mirabai ${ }^{37}$ and 
Princess Satybhama ${ }^{38}$ had for Shri Krishna. In the first scene, my niece exhibited the qualities of Mirabai as she danced a portion of a traditional prayer ${ }^{39}$ to Shri Krishna. In the second scene, my niece and I danced an instrumental ${ }^{40}$ that had no verbal words set to it. I played the role of Satyabhama and my niece played the role of Mirabai. Satyabhama desired to see Shri Krishna but could not find his physical body anywhere. Mirabai takes Satyabhama to pray in the mandir (Hindu place of worship). This is where Satyabhama realizes that Shri Krishna dwells in our hearts and radiates through our good actions. In the third scene, my niece and I successfully danced Mere Dholna, ${ }^{41}$ the Bollywood song, with solely traditional Indian classical dance moves as we remained in our respective characters of Mirabai and Satyabhama.

My niece and I wore traditional Indian classical dance costumes as we danced, which further represented us as classical dancers. This was appropriate because of the meaning of the song lyrics as well as the choreography that explicitly focused on the dancer's love for Shri Krishna. Before we danced, the introducer read a short script that I had written about the scenes. I danced to the words in the script as the introducer read it out loud. I aimed to help the viewers of the dance build background knowledge for the dance.

As my niece and I danced, I felt a sincere sacred, educational gaze from the audience who wanted to learn more about the princesses. I did sense an innocent as opposed to a predatory exotic gaze. This was a curious gaze that wanted to know more about the uniqueness of the dance. I sense this because the spectators' eyes seemed focused with curiosity on the dance. Although most of the event seemed rowdy, the crowd was very quiet during the dance. They cheered vibrantly with great enthusiasm after the dance ended. The religious and cultural critics applauded this dance and repeatedly mention it to me as one of the best dances performed by my niece and me among West Indian Hindus. I feel this is because I maintained an ethic of hybrid responsibility as I choreographed the dance with creativity that blended traditional Indian classical dance and Bollywood dance in the space of hybridity with sensitivity. Thus, I focused more on teaching rather than entertaining.

There were still flaws with the dance that cause me to further think about the usage of creativity. The middle scene of the dance was choreographed with Satyabhama and Mira as devotees of Shri Krishna. Satyabhama lived during ancient times whereas Mirabai lived in modern times. Here, I feel there is a danger that I developed a fictitious scene, although quite a realistic scenario, that distorts Hindu history. If the audience viewed the created scene as history and not as a creatively developed scene, then I run the risk of Orientalizing Hinduism. I will unintentionally add to mythological interpretations of Hinduism if this occurs.

Nevertheless, I am satisfied with the hybrid pedagogy that I used to teach my niece. She often mentions to me that this dance was one of the most profound dances that she has ever engaged in. My niece expressed to me that 
she danced from her heart with love for Shri Krishna as she connected to a Supreme Being through the medium of dance. Together, we frequently dance the song in the private space of our home. When the opportunity presents itself, she repeatedly asks me to dance the song with her on stage. The public requests us to dance this particular song continuously, probably because of the powerful experience that occurs. Through hybrid pedagogy, my niece acknowledged her purpose in the dance to intentionally bond with a Supreme Being. Likewise, I felt a sense of purpose as a Hindu dancer who seeks to connect to a Supreme Being and think deeply about how to live in the world as an interconnected part of humanity. While I was pleased with the hybrid pedagogy that I used to teach my niece, I was dissatisfied with the lack of hybrid pedagogy for the attendees who viewed the dance.

As I draw upon the work of Bhabha, I realize that I cannot return to a pure, accurate history. The introducer who read the script, for the above-mentioned dance, as I performed the dance movements was the only opportunity that I had to engage in de-Orientalized pedagogy with the viewers of the dance. The script mentioned that Satyabhama was an ancient Hindu princess whereas Mirabai was a modern Hindu princess. Thus, it is evident that they did not live historically at the same time. I do not sense the audience viewed the dance as historical. I was also concerned when the audience laughed as I, in the role of Satyabhama, cried intensely because I could not find Shri Krishna's physical body. This was not meant to be humorous but rather was meant to relate the character trait of Satyabhama who was in despair when she was not with Shri Krishna. This almost seemed like a mockery to me who sincerely felt Satyabhama's pain. Nevertheless, I am sure that was not the intent of this seemingly harmless audience. Here, it seems that I became an entertainer for the audience. I am not an "entertainer" or a "performer," but rather I am a Hindu dancer who might at some points "entertain" or "perform," but that is not the goal. My goal is to educate though Hindu dance about Hinduism with postcolonial realities in mind.

Although the dance was well received, I do not sense that I taught the spectators about Shri Krishna, Satyabhama, and Mirabai. Instead, the spectators seemed to enjoy the sacredness of the dance, which was evident in the costume and choreography, but I do not sense that they learned about the character traits of Shri Krishna, Satyabhama, and Mirabai. Although I do not feel that I was able to successfully teach the spectators, I do feel my niece learned a great deal about Satyabhama and Mirabai. I do have a sense of satisfaction knowing that I was able to teach my niece about Hinduism through Hindu dance.

I do not mean to suggest that Bollywood ${ }^{42}$ is always an Orientalized space that endorses a fictionalized version of Indian culture. On the contrary, Bollywood provides a valuable pedagogical space for diasporic cultures to meet to produce something new. What I am suggesting is that what develops in the culture of Bollywood has the ability to cause Orientalism to flourish if 
there is no sensitivity to postcolonial realities. This is important to consider because Bollywood is a hybrid space where cultures inevitably intertwine.

\section{Implications for the creative process}

There is a need to maintain a de-Orientalized knowledge base to develop something new in the space of hybridity with postcolonial realities in mind. If a de-Orientalized knowledge base coupled with an ethic of hybrid responsibility is not present, then there is a great risk that Orientalism will thrive as something new develops. For this reason, it is an ongoing interest to reevaluate the issue of creativity repeatedly since cultures do not remain static but rather are diasporic. It is imperative for dancers across dance genres, both Eastern and Western, to engage in the creative process with sensitivity to confront the problem of Orientalism. Although I provide the example of engaging in the creative process through dance, this philosophical framework is transferable to other disciplines. The key is to maintain a sensitive awareness throughout the creative process to prevent further Orientalism of religion and culture. It is crucial to uphold an ethic of hybrid responsibility for creative innovations in the pedagogical space of hybridity.

Through my self-study, I maintain that it is urgent to develop a deOrientalized knowledge base that sustains an ethic of hybrid responsibility throughout the creative process. At times, my hybrid pedagogy looks very messy in the pedagogical space of hybridity. For me, hybrid pedagogy consists of a few key elements that commonly develop in the hybrid space in which I teach. The educator should pay attention to each individual student in an effort to guide the student to explore the innermost self to find a purpose that extends out into humanity. Once students find their purpose, then educators may guide the students to intentionally aim to explore and fulfill a purpose that connects to the world. As I employ hybrid pedagogy, I focus on building a de-Orientalized epistemological framework, engaging in dialogue, and coming together with a hybrid activity where something new develops. The characteristics of the newness will vary depending upon the nature of the individuals in the space. In some cases, we construct new terminology that we give meaning to. At other times, we compose new choreography through a creative process with our purpose in mind. To maximize the efficiency of the creative process, it is imperative to apply a de-Orientalized knowledge base to develop something new. If the creative process is unmediated by a de-Orientalized knowledge base that maintains an ethic of hybrid responsibility, then there is an opportunity for an Orientalist parasite to thrive.

\section{Notes}

1. Homi K. Bhabha, The Location of Culture (London, UK: Routledge, 1994), 7.

2. Bhabha, 1994, 9. 
3. Edward W. Said, Orientalism (New York, NY: Vintage Books, 1979).

4. Bhabha, 1994.

5. David R. Smock, Interfaith Dialogue and Peacebuilding (Washington, DC: United States Institute of Peace Press, 2002).

6. John Loughran, International Handbook of Self-Study of Teaching and Teacher Education Practices (Dordrecht, the Netherlands: Kluwer Academic, 2004).

7. Joseph Selbie and David Steinmetz, The Yugas: Keys to Understanding Man's Hidden Past, Emerging Present and Future Enlightenment: From the Teachings of Sri Yukteswar and Paramhansa Yogananda (Nevada City, CA: Crystal Clarity Publishers, 2010).

8. BharataMuni, The Natya Sastra of Bharatamuni (Delhi, India: Sri Satguru, 2000).

9. Nandikeśvara and P. S. R. Apparao, Abhinaya darpanam of Nandikeśwara (Hyderabad, India: P.S.R. Appa Rao, 1997).

10. I discuss this in depth in the following article: Sabrina D. MisirHiralall, "Mindfulness as a Pedagogical Tool: Kuchipudi Indian Classical Hindu Dance," Society for the Arts in Religious and Theological Studies 27, no. 1 (2015): 32-39. http://societyarts.org/artsjournal/online-edition/136-online-edition-vol-27-no-1/329-mindfulness-as-a-pedagogicaltool-kuchipudi-indian-classical-hindu-dance.

11. I use the term peer scholars to refer to what many call a "critical friend." I feel the term peer scholar creates a sense of reciprocal appreciation and respect.

12. Ruth St. Denis, Ruth St. Denis, an Unfinished Life; an Autobiography (New York, NY: Harper \& Bros, 1939).

13. Walter Terry, Ted Shawn, Father of American Dance: A Biography (New York, NY: Dial Press, 1976).

14. Ruth St. Denis and Ted Shawn, Denishawn the Birth of Modern Dance the Story of Ruth St. Denis and Ted Shawn (West Long Branch, NJ: Kultur, 1997).

15. Suzanne Shelton, Divine Dancer: A Biography of Ruth St. Denis (Garden City, NY: Doubleday, 1981), 51.

16. Shelton, 1981, 93.

17. Shelton, 1981, 94; St. Denis, 1939.

18. BharataMuni, The Nātya Śāstra. 2nd rev. ed. (Delhi, India: Sri Satguru Publ, 2000).

19. Thomas K. Hagood, A History of Dance in American Higher Education: Dance and the American University (Lewiston, NY: E. Mellen Press, 2000), 65.

20. St. Denis and Shawn, 1997); Edmund F. Penney, Gertrude Marks, Charles Curran, and Joan Van Grove, The Dancing Prophet (Derry, NH: Chip Taylor Communications, 1999).

21. BharataMuni, 2000, 30.

22. Rāmacandra Prasāda, Tulasīdāsa's Śrī Rāmacaritamānasa: The Holy Lake of the Acts of Rāma (Delhi, India: Motilal Banarsidass Publishers, 1991), 13.

23. Joan Erdman, "Dance Discourses: Rethinking the History of the "Oriental Dance." In Moving Words: Re-writing Dance (London: Routledge, 1996), 288-305, 290.

24. Said, Orientalism, 1978.

25. Gay Morris, "www.GaneshShivaMandir.org." (accessed January 23, 2014).

26. I do not refer to the western part of India. Instead, I employ the term West Indian, as it is commonly used, to refer to Caribbean Hindus who have Indian ancestry.

27. "Bollywood.com: Entertainment news, movie, music and fashion reviews." http://www. bollywood.com/ (accessed January 23, 2014).

28. Kush Varia, Bollywood: Gods, Glamour, and Gossip (London, UK: Wallflower, 2012).

29. Varia, 2012, 4.

30. Everybody on Dance Floor. Level 7 Level 7. Track 10 (New Delhi, India: T-Series, 2009).

31. Bageshree Vaze and Vineet Vyas, Khanak Music for Indian Classical Dance (Mumbai, India: Times Music India, 2008). 
32. Yogananda, The Bhagavad Gita: God Talks with Arjuna: Royal Science of God Realization (Los Angeles, CA: Self Realization Fellowship, 1995).

33. Mīrābāì and A. J. Alston, The Devotional Poems of Mīrābāī (Delhi, India: Motilal Banarsidass, 1980); Mīrābai and Krishna Prakash Bahadur, Mira Bai and Her Padas (New Dehli, India: M. Manoharlal, 2002); Bankey Behari, Bhakta Mira (Bombay: Bharatiya Vidya Bhavan, 1971); R. Bhatnagar, "Meera's Medieval Lyric Poetry in Postcolonial India: The Rhetorics of Women's Writing in Dialect as a Secular Practice of Subaltern Coauthorship and Dissent," Boundary 2 31, no. 3 (2004): 1-46.; S. M. Pandey and Norman Zide, "Mīrābāī and Her Contributions to the Bhakti Movement," History of Religions 5, no. 1 (1965): 54-73.

34. Mīrābāī and Alston, 1980.

35. Pritam and Sameer, Bhool bhulaiyaa (New Delhi, India: Super Cassettes Industries, 2007).

36. "Gyaan Ka Saagar-Home." Gyaan Ka Saagar. http://www.gyaankasaagar.com (accessed January 23, 2014).

37. Mīrābāī and Alston, 1980; Mīrābai and Bahadur, 2002; Behari, 1971; Bhatnagar, 2004, 1-46.; Pandey and Zide, 1965, 54-73.

38. C. L. Goswani and M.A. Shastri, Srimad Bhāgavata Mahāpurāna. 11th ed. (Gorakhpur, India: Gita Press, 2010).

39. Āśita Deśāī and Hemant Mattani. Track 2, Krishnavali Divine Chants of Krishna (Leicester, UK: Sona Rupa, 2004).

40. Bageshree Vaze and Vineet Vyas, Khanak Music for Indian Classical Dance (Mumbai, India: Times Music India, 2008).

41. Pritam and Sameer, 2007.

42. Ajay Gehlawat, Reframing Bollywood: Theories of Popular Hindi Cinema (New Delhi, India: SAGE Publications, 2010). 